\title{
Government (non-)formation in contemporary Lebanon: sectarianism, power-sharing, and economic immobilism.
}

Catherine Batruni, Marcus Hallinan

\begin{abstract}
Four months after the parliamentary elections, the Lebanese state is still without a government. Politicians have been hindering the configuration of a new cabinet in order to maximise their own personal gains. This paper probes the positions of the most prominent political parties in the country, namely the Lebanese Forces, Free Patriotic Movement, Progressive Socialist Party, Lebanese Democratic Party, Future Movement, and Hezbollah, and examines the repercussions of this political vacuum on the economy. We raise the question: why does Lebanon continually find itself in this recurring situation where it is incapable of forming a timely government after elections? We argue that the political structure and sectarian arrangement of the Lebanese government allow such dysfunction to flourish through an absence of accountability measures in the constitution and a prioritizing of sectarian equilibrium as the primary factor in electing a government.
\end{abstract}

Keywords: Lebanese Sectarian System, Power Dynamics, Lebanese Politics

To cite this paper: Catherine Batruni, Marcus Hallinan, "Government (non-)formation in contemporary Lebanon: sectarianism, power-sharing, and economic immobilism. ", Civil Society Knowledge Center, Lebanon Support, September, 2018 . DOI: 10.28943/CSKC.002.60002.

[ONLINE]:

https://civilsociety-centre.org/paper/government-non-formation-contemporary-lebanon-sectarianismpower-sharing-and-economic

\section{Introduction}

Contemporary Lebanese political life has been one of maximal delays. Customarily, parliamentary elections must transpire every 4 years, although this is not explicitly stated in the constitution. ${ }^{[1]}$ After 9 years of regular postponements and the fabrication of a new electoral law, Lebanon held its most recent parliamentary elections on May 6, 2018. Indeed, political quagmires continue to define the country, as a government has yet to be formed 4 months after the elections. The cause - bickering and horsetrading between various blocs and parties - is hardly a new one. From its inception the Lebanese state was founded upon the notions of consensus and power sharing between 18 different religious confessions, $^{[3]}$ an arrangement that has been detrimental, as this paper will demonstrate.

Following the elections of May 6, Saad Hariri was re-appointed as Prime Minister for the third time by a new parliament, and was tasked with creating a government by May 21. Although a new parliament was in place, the government was technically not fully formed yet; there still remained numerous ministerial positions in the cabinet to fill, formally known as the Council of Ministers. The standard formula set by previous Lebanese governments in the post-Taef era ${ }^{[4]}$ is for the Prime Minister to 
nominate a group of people that reflects a sectarian equilibrium, which the President must approve. ${ }^{[5]}$ All governments in the postwar era have had around 30 ministers. ${ }^{[6]}$ This number is not a legal requirement; no precise numbers for this governing body are put forth in the constitution; the only prerequisite is equal representation of Christians and Muslims, a condition that has been agreed upon for all government structures. "Hariri is aiming to form a "national unity government in which no one wins over the other," ${ }^{[8]}$ implying that no sect feels that another is exercising hegemony over the government.

As of September 2018, Lebanon is still without a government. The causes behind this predicament are twofold. First, we argue that the structure of the political system as laid out in the Lebanese constitution facilitates this situation by deliberately excluding laws that would force the state to create a government within a reasonable deadline following elections. Secondly, we argue that the emphasis on the need for sectarian equilibrium in government institutions also promotes this recurring situation, at the expense of competence and specialisation.

\section{Déjà Vu: Sectarian Strife Leads to Political Entanglement}

The present crisis is not the first time that Lebanon was without a government for a substantial period of time. After the elections of 2014, Lebanon was bereft of a government for 10 months. ${ }^{[.9}$ This was double the amount of time it took in 2009, when Lebanon had no government for 5 months. ${ }^{1.0]}$ In both instances, a lack of legal boundaries regarding timelines for government formation, and the perpetuation of sectarianism rather than Lebanese nationalism, exacerbated the situation. These two factors enabled the crises to drag on with seemingly no end in sight. Laws and agreements prioritizing Christian-Muslim symmetry in government, with no mention of requirements of educational training or occupational expertise, continue to push unproductive politicians into government. Such Byzantine bureaucracy was epitomised in 1955 when a "Sunni ex-diplomat headed the Ministry of Public Works, while a Maronite engineer became the foreign minister." "Based on their occupational backgrounds, neither individual was suitably qualified for these ministries.

How are the issues of sectarian balancing and lack of constitutional regulations manifesting in this current crisis? One of the overarching reasons for the current imbroglio is disagreement on representation between the two main Christian parties: the Free Patriotic Movement (FPM) and the Lebanese Forces (LF). On the one hand, the LF claims that it deserves more representation in the new government due to the doubling of its parliamentary seats in the last elections. ${ }^{[12]}$ Samir Geagea, executive chairman of the LF, explained in a televised interview on the local MTV network on August 22 that his party is entitled to 6 seats in the new cabinet. ${ }^{[13]}$ Geagea argued that this number is based on the "Maarab Understanding," an agreement signed by the LF and FPM in 2016 that would achieve reconciliation among the two Christian parties which have been feuding for approximately 30 years. According to his calculations, Geagea maintained that his party should have 6 seats in the new government, while the FPM is reportedly seeking 11 seats. ${ }^{[15]}$ Rendering this situation even more complex, the FPM has an alliance, "lubnan al qawi" (Strong Lebanon), which is led by Gibran Bassil, head of the FPM, caretaker Foreign Minister, and son-in-law of President Michel Aoun. Strong Lebanon is made up of 29 lawmakers; ${ }^{[16]}$ this includes FPM members and independent individuals who ran in Mount Lebanon during the May elections on the same lists. ${ }^{[17]}$ Geagea accused Bassil of conflating the FPM with Strong Lebanon to procure more ministerial seats than the FPM actually deserves. Geagea contended in his MTV interview that FPM should only have 8 ministers in the cabinet, instead of the 11 
that they are calling for. ${ }^{[18]}$

After meeting with Hariri on August 29, Geagea allegedly agreed to pursue "service-related" ministries for his party if the LF was not granted any sovereign ministries or the position of deputy prime minister. The LF is asking for ministers in 4 out of 5 of the following: the Ministry of the Interior, the Ministry of Foreign Affairs, the Ministry of Finance, the Ministry of Social Affairs, and the Ministry of Energy and Public Works. The FPM retorted that they would only agree to the LF securing no more than 2 of these ministries. ${ }^{[19]}$ This struggle for Christian monopolisation in the government is strikingly reminiscent to the battles for Christian dominance that transpired in the late 1980s towards the end of Lebanon's 15 year civil war, ${ }^{[20]}$ highlighting the fact that sectarian politics often brings about the opposite effect of what was originally intended.

Another sectarian issue that is upholding the stalemate is the question of Druze representation. In the previous 30-member cabinet, Druze held 3 cabinet positions. "Walid Jumblatt, leader of the Progressive Socialist Party, is demanding that Hariri appoint 3 ministers from his party for the next Council of Ministers. His Druze rival and Hezbollah ally, Talal Arslan, leader of the Lebanese Democratic Party, is demanding that he be granted 1 ministry; this is despite Arslan capturing only 1 of 8 Druze parliamentary seats in the last election. Arslan is accusing Jumblatt of "monopolising" the Druze sect's share of cabinet seats, and Arslan vows to reject any Druze representation in the new government that does not gain his approval.

Adding more pressure to the already strenuous Druze infighting is the inter-sectarian meddling of the FPM's Gibran Bassil. Bassil is suggesting to move forward with the nomination of his ally, Arslan, directly interjecting a Christian party's influence into a strictly Druze political matter. ${ }^{[2]}$ Dr. Wassim Abu Ltaif, a lecturer in political science at the Lebanese American University, states that many scholars believe that the Druze issue is linked to a wider Christian fracture, explaining: "Once you resolve the Christian problem in government, then your ability to resolve the Druze issue could be easily found." According to Abu Ltaif, this is because Jumblatt will not want to be the sole remaining obstacle to the formation of a government.

Yet an additional sectarian issue is that of Sunni representation outside of the Future Movement (FM), the mainstream Sunni party of Saad Hariri. The FM insists that its party should be assigned all seats that are available for the Sunni sect, regardless of the fact that their presence in parliament significantly decreased after the most recent election. ${ }^{[25]}$ Moreover, Sunnis who are unaffiliated with the FM are looking to have a separate voice in the new government. ${ }^{[26]}$

The last major political party, Hezbollah, is not participating in the bickering but is still involved indirectly. Hezbollah and its allies walked away with a clear majority from May's election - securing more than 70 of the 128 seats in parliament. ${ }^{[27]}$ Mohanad Hage Ali, of the Carnegie Middle East Center, explained in an Al-Jazeera television interview that Hezbollah is currently seeking to nominate proHezbollah, pro-Assad, or pro-March 8 candidates for the Druze and Sunni cabinet positions. Ali describes Hezbollah's intentions as wishing to "break the monopoly" that Jumblatt and Hariri's parties have previously enjoyed in the cabinet. ${ }^{[28]}$ Ironically, Hariri, who was "gentlemanly kidnapped" by the Saudis in 2017, is now responsible for appropriating more power to Hezbollah, an Iranian and Syrian 
ally.

This is simultaneously occurring while Hariri's allies, mainly Saudi Arabia and the United States, have been advocating for Lebanon to have "Hezbollah...disarmed/disbanded/merged into the Lebanese army." Abu Ltaif speculates that Hezbollah is strategically observing all the political negotiations amongst the Christian, Sunni, and Druze sects in order to eventually present a viable solution to forming a government if one cannot be agreed on in the meantime. ${ }^{[.30]}$ However, Hezbollah usually does not seek sovereign ministries where the executive has vast powers, such as the areas of defence, interior, foreign affairs, and finance, as a way of reducing international angst towards the Lebanese government as a whole. ${ }^{[31]}$ This may be true, as Lebanon depends heavily on international support to hold its frail economy together, supply military aid, and help manage approximately 1 million Syrian refugees within its borders. ${ }^{[32]}$ Dr. Hilal Khashan, a professor of political studies at the American University of Beirut, posits that Hezbollah is seeking to finally acquire official governmental legitimisation for their military "resistance" component - a position Hairi will be unable to agree with. Moreover, due to the war in Syria coming to an end and the unattractive consequences of starting a war with Israel, Khashan points out that Hezbollah is aiming to stay politically relevant by developing a "domestic niche in Lebanese affairs" by claiming to "lead the battle against corruption in Lebanon"

Finally, President Aoun wishes to nominate one, two, or three people to the Council of Ministers - the exact number he will be able to nominate remains unclear. The Lebanese constitution does not explicitly stipulate that the President can name a specific number of ministers. It has been made known that Aoun wants to nominate the deputy prime minister and the Minister of Defence. ${ }^{[35]}$ However, the exact number of ministers President Aoun ultimately assigns to the government is crucial, explains Abu Ltaif. First, Abu Ltaif highlights the fact that Aoun was staunchly opposed to President Michel Suleiman (2008-2014) wanting to assign up to 3 ministers during his tenure, adding a layer of hypocrisy and thereby confirming the need for constitutional regulations on this matter. More importantly, opponents of Aoun and the FPM realize that any appointments he makes to the cabinet will be aligned with FPM appointees, totalling 10 or more cabinet seats that will give Aoun and the FPM veto power according to the one-third veto provision in the constitution.

The sectarian structure of the government as set forth in the constitution inherently defines citizens on the basis of their confession, rather than promoting a unified Lebanese identity. Dr. Tamirace Fakhoury, an associate professor of political science and international affairs at the Lebanese American University, describes Lebanon's political arrangement as one that "conflates sectarianism with decision-making and political representation," ultimately resulting in political blocs acting as "sectarian gatekeepers vying for resources and political power." parties in Lebanon are sectarian in nature. Each of the major political parties discussed above largely appeal to a specific sect and are frequently at odds with each other. Secular political parties in Lebanon have not experienced nearly as much popularity as political parties with sectarian identities have.

Disagreements in any political system worldwide are expected, but the Lebanese case is exceptional in that the constitution is deliberately vague and ambiguous. It does not set a number of ministries or enforce deadlines within which to create a new government following parliamentary elections. Nor does it stipulate that politicians can only be responsible for one ministry. In 1987, for example, 10 ministers 
held 16 portfolios. ${ }^{[399]}$ Such a broad constitutional context encourages and perpetuates serious delays that regularly result in political deadlock and prevent the development of a modern polity. Moreover, Fakhoury conveys that political deadlocks in "power-sharing system" types of governments similar to Lebanon's, including those in Germany, Switzerland, and Belgium, are not unheard of. ${ }^{400]}$ However, Lebanon differentiates itself from others who utilize this system of government due to having no "ingrained institutional devices that limit and contain deadlocks." ${ }^{[41]}$ Khashan also emphasizes that "delays in cabinet formation are the norm instead of the exception in Lebanese politics." meantime, the economy is suffering immensely.

\section{The impact on the national economy in the midst of political indifference}

The primary effect of the current political quandary is damage to the Lebanese economy, which is heavily dependent on tourism, construction, and finance. ${ }^{[43]}$ In April 2018, France hosted a conference in Paris to promote development and reforms in Lebanon. The outcome of this meeting, known as "CEDRE", was the pledging of $\$ 12$ billion US dollars from various foreign donors. However, approximately $85 \%$ of these promised funds are loans ${ }^{[45]}$ that will end up increasing Lebanon's debt-toGDP ratio from $150 \%$ to $180 \%$ in 5 years, the repayment of which will use up three-fifths of the government's annual income. ${ }^{[46]}$ Lebanon already ranks third in terms of countries with the highest public debt, falling just short of Japan and Greece. ${ }^{[47]}$ Nevertheless, wise discretion in the expenditure of the CEDRE funds would strengthen the stagnating economy and bolster the country's deficient infrastructure. This aid package cannot be spent before a government is actually formed. ${ }^{[48]}$

The economy may have much to gain from opening relations with Syria, another urgent reason to finalise a new government as soon as possible. However, there are bitter disagreements among various parties regarding what Lebanese official relations should be, if any, with Syria. Hariri believes that Syria is denying Lebanese goods passage through the key Jordanian-Syrian Nassib border crossing, the only land route for Lebanese products to reach Jordan and the Gulf, and would most likely reopen if Lebanese-Syrian relations began. ${ }^{[49]}$ Syria has also offered Lebanon electricity, a resource that has not been available in Lebanon for 24 hours a day since the onset of the country's civil war in $1975 .^{501}$ The Lebanese are also angling to secure a portion of the massive reconstruction efforts that will eventually take place in Syria, ${ }^{[51]}$ estimated by the World Bank to total as much as $\$ 200$ billion. Tripoli, in northern Lebanon, is being eyed by many as a possible transit point for construction materials that will make their way to Syria. The possibility of Lebanese banks financing the rebuilding of the Syrian infrastructure, as well as opening retail branches within Syria, is also being planned. ${ }^{[52]}$ Citing the pivotal role Lebanon could potentially play in Syria's reconstruction, Global Finance went as far as to feature an article in April 2018 entitled "Lebanon Ready to Rebuild Syria."

Another pressing economic project concerns the airport. The Lebanese Public Works Minister, Youssef Fenianos, stated that Beirut's Rafik Hariri International Airport is in need of a $\$ 100$ million dollar investment for renovation and expansion. ${ }^{[54]}$ This is without mentioning the possible economic boon Lebanon's offshore oil and gas drilling can potentially bring, which is set to begin in 2019 in order to explore whether there are commercial reserves and scales. ${ }^{[55]}$ However, these potential opportunities can be limited or completely missed if a government in Beirut does not exist and instability prevails. Regular warnings to the government from Lebanese economic agencies on the pressing need to form a 
government continue to fall on deaf ears as of September $6 .^{[56]}$ President Aoun paid lip service to the importance of prioritising the economy in a meeting with politicians on September 7 without actually coming up with a concrete plan, ${ }^{[57]}$ while the Minister of Finance falsely claimed that the economic situation was "sound" and that economic collapse is not imminent.

Given all of the above, it is unsurprising that the World Economic Forum ranked "government instability" as the number one problematic factor for doing business in Lebanon in its 2016 report. ${ }^{[59]}$ Nor is it unexpected that Lebanon ranks 136 out of 176 for most corrupt nations by Transparency International.

\section{Conclusion}

Who will Prime Minister Hariri ultimately nominate? All blocs that are currently in parliament wish to have representation in the cabinet. Parliament has the right to reject Hariri's proposed government, in which case he would no longer be the Prime Minister. Parliament would then have to nominate a new Prime Minister and revert to square one. The Lebanese cannot afford to be faced with such a counterproductive scenario, hence the urgent need to amend the constitution to implement regulations on government formation, including penalties for not meeting deadlines, and deconfessionalise the distribution of political positions.

At this point, it is quite difficult to clearly ascertain when a government may be formed. Some sources posit that a new government will be formed any day now, while others maintain that Lebanon will be without a government until 2019. ${ }^{[62]}$ Such ineffective traditions necessitate government formation within a reasonable deadline following elections to keep the country economically afloat. Furthermore, political sectarianism has been promoted at the expense of competence and specialisation. It would behoove the Lebanese government to implement one of the objectives of the Taef Accord, specifically the "abolition of political confessionalism" which the document claims is "a fundamental national objective."

\footnotetext{
Historically, this has been the tradition; the Lebanese constitution does not stipulate when elections should be held. See the Lebanese Constitution, Arabic, available for download at http://www.presidency.gov.lb. [Last accessed September, 5 2018].
}

\footnotetext{
At the time of writing this article, the government remains deadlocked.
} 
[3] Kais Firro, Inventing Lebanon: Nationalism and the State Under the Mandate, London, I.B. Tauris, 2002.

[4] The document known as the "Taef Agreement" brought the Lebanese civil war of 1975-1990 to an end. It was approved by the Lebanese Parliament in 1989. Arabic,

http://www.presidency.gov.lb/Arabic/LebaneseSystem/Documents/TaiifAgreementn.pdf [last accessed September 6, 2018].

[5] Lebanese Constitution, Article 64, paragraph 2, Arabic, available for download at http://www.presidency.gov.lb. [Last accessed September, 6, 2018].

${ }^{[6]}$ Paul Salem, "Framing Post-War Lebanon: Perspectives on the Constitution and the Structure of Power," English, Mediterranean Politics 3.1 (1998), p. 19.

${ }^{[7}$ This is not explicitly stated in the constitution. See the Lebanese Constitution, Arabic, available for download at http://www.presidency.gov.lb. [Last accessed September, 6, 2018].

${ }^{[8]}$ Rajeh al-Khoury, "Welcome to the Government Coma," Annahar, Arabic, September 4, 2018, https://newspaper.annahar.com/article/854065 [Last accessed September, 6, 2018].

[9] Laila Bassam \& Erika Solomon, "Lebanon Forms Government After 10-Month Deadlock," Reuters, 
English, February 15, 2014, https://www.reuters.com/article/us-lebanon-government/lebanon-formsgovernment-after-10-month-deadlock-idUSBREA1E07S20140215 [last accessed August 30, 2018].

${ }^{[10]}$ "As Cabinet Formation Drags, Lebanon Risks Economic Tailspin," Agence France Presse, English, August 31, 2018,

https://www.france24.com/en/20180831-cabinet-formation-drags-lebanon-risks-economic-tailspin [last accessed August 31, 2018].

${ }^{[111]}$ Thomas Collelo, ed., Lebanon: A Country Study, English, Washington D.C.: GPO for the Library of Congress, 1989, p. 149.

[12] "FPM Hits Back After Geagea Interview Over Government Delay," Daily Star, English, August 23, 2018,

https://www.dailystar.com.lb/News/Lebanon-News/2018/Aug-23/460981-If-not-hindering-govt-formationgeagea.ashx [last accessed August 30, 2018].

${ }^{[13]}$ Samir Geagea, Interview on "Bi Mawdouiyeh", MTV Network, Arabic, August 22, 2018, https://www.youtube.com/watch?v=mWl1wQJY5jY (Part 1) and https://www.youtube.com/watch?v=HY19ivNL4H0 (Part 2) [last accessed August 30, 2018].

[14] "Contacts Between FPM, Lebanese Forces to Protect 'Maarab Understanding,"' Asharq Al-Awsat, English, December 27, 2017, https://aawsat.com/english/home/article/1125231/contacts-between-fpmlebanese-forces-protect-\%E2\%80\%98maarab-understanding\%E2\%80\%99 [last accessed August 30, 2018]. 
${ }^{[15]}$ Samir Geagea, Interview on "Bi Mawdouiyeh”, August 22, 2018.

Samir Geagea, Interview on "Bi Mawdoulyeh", August 22, 2018.

${ }^{[16]}$ "FPM Hits Back After Geagea Interview Over Government Delay," Daily Star, English, August 23, 2018,

https://www. dailystar.com.lb/News/Lebanon-News/2018/Aug-23/460981-If-not-hindering-govt-formationgeagea.ashx [last accessed August 30, 2018].

${ }^{[17]}$ Lebanese Elections Official Website, English, https://www.lebaneseelections.com/alliance/freepatriotic-movement-independents [last accessed September 7, 2018].

${ }^{[18]}$ Samir Geagea, Interview on "Bi Mawdouiyeh”, August 22, 2018.

[19] Joseph Haboush, "Hariri, Bassil to Hold Key Talks in Next 48 Hours," Daily Star, English, August 31 , 2018,

https://www.dailystar.com.lb/News/Lebanon-News/2018/Aug-31/461851-hariri-bassil-to-hold-key-talksin-next-48-hours.ashx [last accessed August 31, 2018].

${ }^{[20]}$ Sabine Owais, "War of Abolition of Christian Politics - Christian and Constitutional Christian - Sunnis Overthrow the Government?" Annahar, Arabic, September 6, 2018, https://newspaper.annahar.com/article/855532 [last accessed September 7, 2018]. 
[21] "Premier Hariri Admits Moves For New Cabinet 'Still In the Soup'," Albawaba, English, September 5, 2018, https://www.albawaba.com/news/premier-hariri-admits-moves-new-cabinet-still-soup-1181904

[22] "Divide Persists Between Arslan and Joumblatt," Daily Star, English, August 2, 2018, http://www.dailystar.com.lb/News/Lebanon-News/2018/Aug-02/458820-divide-persists-between-arslanand-joumblatt.ashx [last accessed September 1, 2018].

${ }^{[23]}$ Wassim Abu Ltaif, interview by Catherine Batruni, Beirut, August 30, 2018.

[24] Idem.

J25] Joseph Haboush, "Hariri, Bassil to Hold Key talks in Next 48 Hours," Daily Star, English, August 31, 2018,

https://www.dailystar.com.lb/News/Lebanon-News/2018/Aug-31/461851-hariri-bassil-to-hold-key-talksin-next-48-hours.ashx [last accessed August 31, 2018].

[26] "Hariri: The Dispute Over the Portfolios is Useless and the Government Formula Presented by them Translates to the Results of the Parliamentary Elections," Annahar, Arabic, September 4, 2018, https://nahar.news/854839 [last accessed September 7, 2018]. 
[27] Tom Perry and Laila Bassam, "Lebanon Hits Major Logjam After Election," US News, English, August 3, 2018, https://www.usnews.com/news/world/articles/2018-08-03/lebanon-hits-political-logjam-afterelection last accessed September 1, 2018].

${ }^{[28]}$ Zeina Khodr, "Political Parties in Lebanon Struggle to Form Government," Al Jazeera, English, August 10, 2018, https://www.aljazeera.com/news/2018/08/political-parties-lebanon-struggle-formgovernment-180810110840616.html [last accessed September 1, 2018].

[29] Robert Fisk, "Lebanon is on a Tightrope, Balancing Saudi, Iranian, and Western Interests - Its Position is Precarious," Independent, English, August 30, 2018], https://www.independent.co.uk/voices/lebanon-syria-middle-east-robert-fisk-saudi-iranian-westerninterests-precarious-position-a8514891.html [last accessed September 2, 2018].

${ }^{[30]}$ Wassim Abu Ltaif, interview by Catherine Batruni, Beirut, August 30, 2018.

[31] David Enders, "Lebanon's Leaders and Marathon Task of Cabinet Formation," National, English, June 4, 2018, https://www.thenational.ae/world/mena/lebanon-s-leaders-and-the-marathon-task-ofcabinet-formation-1.736823 [last accessed September 1, 2018].

${ }^{[32]}$ Ben Hubbard and Hwaida Saad, "Lebanon Elections Boost Hezbollah's Clout," New York Times, May 7, 2018, https://www.nytimes.com/2018/05/07/world/middleeast/lebanon-election-hezbollah.html [last accessed September 5, 2018]. 
${ }^{[33]}$ Hilal Khashan, interview by Marcus Hallinan, Skype, September 11, 2018.

${ }^{[34]}$ Ibid.

${ }^{[35]}$ Youssef Diab, “Lebanon's Cabinet Formation Drags," Asharq Al-Awsat, English, August 31, 2018, https://aawsat.com/english/home/article/1379051/lebanon\%E2\%80\%99s-cabinet-formation-drags [last accessed August 31, 2018].

${ }^{[36]}$ Wassim Abu Ltaif, interview by Catherine Batruni, Beirut, August 30, 2018.

Tamirace Fakhoury, interview by Catherine Batruni, Email, September 16, 2018.

[38] Nizar Abdel-Kader, "Stagnation Rules in Lebanon's Secular Political Parties," Daily Star, English, July 6, 2007, http://www.dailystar.com.lb/Opinion/Commentary/2007/Jul-06/115621-stagnation-rules-inlebanons-secular-political-parties.ashx [last accessed September 11, 2018].

${ }^{[39]}$ Thomas Collelo, ed., Lebanon: A Country Study, English, Washington D.C.: GPO for the Library of Congress, 1989, p. 149. 
${ }^{[40]}$ Tamirace Fakhoury, interview by Catherine Batruni, Email, September 16, 2018.

${ }^{[41]}$ Ibid.

${ }^{[42]}$ Hilal Khashan, interview by Marcus Hallinan, Skype, September 11, 2018.

${ }^{[43]}$ "When the Music Stops: Lebanon's Economy Has Long Been Sluggish. Now a Crisis Looms," Economist, English, August 30, 2018, https://www.economist.com/middle-east-andafrica/2018/09/01/lebanons-economy-has-long-been-sluggish-now-a-crisis-looms [last accessed August 31, 2018].

${ }^{[44]}$ CEDRE Conference official website, English and French, https://www.diplomatie.gouv.fr/en/countryfiles/lebanon/events/article/lebanon-cedre-conference-06-04-18 [last accessed August 31, 2018].

${ }^{[45]}$ Joint Statement of CEDRE Conference, CEDRE Conference official website, French, April 6, 2018, https://www.diplomatie.gouv.fr/IMG/pdf/fr_finale_cle8c8318.pdf [last accessed September 7, 2018].

${ }^{[46]}$ "When the Music Stops: Lebanon's Economy Has Long Been Sluggish. Now a Crisis 
Looms," Economist, English, August 30, 2018, https://www.economist.com/middle-east-andafrica/2018/09/01/lebanons-economy-has-long-been-sluggish-now-a-crisis-looms [last accessed August 31, 2018].

[47] "As Cabinet Formation Drags, Lebanon Risks Economic Tailspin," Agence France Presse, English, August 31, 2018,

https://www.france24.com/en/20180831-cabinet-formation-drags-lebanon-risks-economic-tailspin [last accessed August 31, 2018].

${ }^{[48]}$ "As Cabinet Formation Drags, Lebanon Risks Economic Tailspin," Agence France Presse, English, August 31, 2018,

https://www.france24.com/en/20180831-cabinet-formation-drags-lebanon-risks-economic-tailspin [last accessed August 31, 2018].

${ }^{449]}$ "Hariri Hits Back Over Government Delay on Criticism," Daily Star, English, August 28, 2018, http://www.dailystar.com.Ib/News/Lebanon-News/2018/Aug-28/461449-hariri-to-touch-on-govtformation-stl.ashx [last accessed September 1, 2018].

${ }^{[50]}$ Robert Fisk, "Lebanon is on a Tightrope, Balancing Saudi, Iranian, and Western Interests - Its Position is Precarious," Independent, English, August 30, 2018, https://www.independent.co.uk/voices/lebanon-syria-middle-east-robert-fisk-saudi-iranian-westerninterests-precarious-position-a8514891.html [last accessed August 31, 2018]. 
[51] "As Cabinet Formation Drags, Lebanon Risks Economic Tailspin," Agence France Presse, English, August 31, 2018,

https://www.france24.com/en/20180831-cabinet-formation-drags-lebanon-risks-economic-tailspin [last accessed August 31, 2018].

${ }^{[52]}$ Alex Dziadosz, "Lebanon's Bankers See Reconstruction Role in Syria," Financial Times, English, November 20, 2017, https://www.ft.com/content/cfc1929c-c0bd-11e7-b8a3-38a6e068f464 [last accessed September 7, 2018]

${ }^{[5]}$ Chloe Domat, "Lebanon Ready to Rebuild Syria," Global Finance, English, April 11, 2018, https://www.gfmag.com/magazine/april-2018/lebanon-ready-rebuild-syria [last accessed September 9, 2018].

${ }^{[54]}$ "Fenianos: I am not in Charge of the Airport Crisis and it Needs $\$ 100$ Million," Annahar, Arabic, August 30, 2018, https://nahar.news/851338 [last accessed September 6, 2018].

[55] Lisa Barrington, "Lebanon Begins Offshore Oil and Gas Exploration," Reuters, English, May 29, 2018,

https://www.reuters.com/article/us-natgas-lebanon/lebanon-begins-offshore-oil-and-gas-explorationidUSKCN1IU15F [last accessed September 6, 2018].

[56] "Economic Agencies Warn of Repercussions in Delaying the Formation of the Government," Annahar, Arabic, September 6, 2018, https://nahar.news/856087 [last accessed September 7, 2018]. 
[57] "Aoun: The March of Reforms in Lebanon Has Begun," Al-Dostor, Arabic, September 7, 2018, https://www.dostor.org/2313451 [last accessed September 7, 2018].

[58] "Khalil and Kanaan From Baabda: The Financial Situation is Sound," Annahar, Arabic, September 7, 2018, https://nahar.news/856528 [last accessed September 8, 2018].

[59] "Lebanon: Global Competitive Index 2017-2018 Edition," English, 2018, http://www3.weforum.org/docs/GCR2017-2018/03CountryProfiles/Standalone2-pagerprofiles/WEF_GCI _2017_2018_Profile_Lebanon.pdf [last accessed September 6, 2018].

${ }^{[60]}$ Hussain Abdul-Hussain, "New Political Parties Challenge Lebanon's Oligarchy," Arab Weekly, English, August 2017, https://thearabweekly.com/new-political-parties-challenge-lebanons-oligarchy [last accessed September 11, 2018].

[61] "Hariri to Present Government Line-Up in Coming Days: Rai," Daily Star, English, August 29, 2018, https://www.dailystar.com.lb/News/Lebanon-News/2018/Aug-29/461659-hariri-to-present-govt-line-up-incoming-days-rai.ashx [last accessed August 30, 2018].

[62] "Lebanon: New Government Could Be Pushed to 2019," Albawaba News, English, August 29, 2018, https://www.albawaba.com/news/lebanon-new-government-formation-could-be-pushed-2019-1178924 
[last accessed August 30, 2018].

${ }^{[63]}$ The Taef Accords, Article 2, Arabic,

http://www.presidency.gov.lb/Arabic/LebaneseSystem/Documents/TaiifAgreementn.pdf [last accessed September 6, 2018]. 